\title{
Electronic Loyalty in Social Commerce: Scale Development and Validation
}

\author{
Bui Thanh Khoa ${ }^{* a}$, Minh Ha Nguyen ${ }^{b}$ \\ ${ }^{a}$ Industrial University of Ho Chi Minh City, Vietnam \\ ${ }^{\mathrm{b}}$ Finance, Economics and Management Research Group; Ho Chi Minh City Open University, Vietnam
}

\begin{abstract}
Loyalty is an important key performance indicator to assess a business's success, especially in an online business environment with fierce competition. The explosion of social networking sites has created a new form of business: social commerce. Simultaneously, the scale of loyalty in online transactions has some limitations; hence, this research aims to develop and validate an electronic loyalty scale in the context of social commerce. The study used a mixed research method with two phases of a sequential exploratory strategy. Qualitative research generated the scale and was used in the initial filtering to develop an e-loyalty scale for social commerce. This study conducted two quantitative studies with 715 social commerce shoppers in five developed areas in Vietnam: Ho Chi Minh City, Ha Noi City, Hai Phong City, Da Nang City, and Binh Duong Province. Based on our research survey and literature review, the research results showed that electronic loyalty in social commerce is expressed in three dimensions: preference, interaction, and personal information's disclosure. Then, the research proposed several relevant implications for other researchers and administrators of online businesses.
\end{abstract}

Keywords: electronic loyalty (e-loyalty), interaction, personal information's disclosure, preference, scale development and validation, social commerce (s-commerce).

JEL Classification: M10, M31 


\section{Introduction}

Earning and retaining loyal customers is one of the most reliable success strategies for offline and online sellers. However, acquiring and maintaining customers' loyalty is hard in the online environment because the competition is just a few mouse clicks away (Srinivasan et al., 2002). Social commerce (hereafter, s-commerce) has certain advantages over traditional stores, including: greater flexibility, deeper market penetration, lower costs, faster transactions, more extensive product range, customization, and convenience. S-commerce is a subset of electronic commerce, which refers to commercial transactions through social media, social networks, and web 2.0 technology (Turban et al., 2017). In addition to trading activities, such as electronic commerce, s-commerce supports online interactions between sellers and buyers. At the same time, through social networking, the potential for personalization is also enhanced. Therefore, promoting the advantages of s-commerce is crucial for both businesses and researchers. Available alternative services and the instant availability of information lead to fierce price competition and the loss of loyalty to an s-commerce site. Hence, if a company wants to maintain loyalty and succeed in business, it needs to develop deep insights into the nature of loyalty (Liang and Turban, 2011).

Brand loyalty is the preferred response, attitude, and behavior of customers concerning certain brands in a product group. Loyalty is a biased buying process that begins with a consumer's psychology, which creates a favorable attitude toward repeated shopping (Jacoby and Kaplan, 1972; Kotler et al., 2019). Loyalty is an absolute commitment that a customer will continue to buy or be interested in a product/service in the fu- ture, resulting in subsequent purchases of the same brand or its affiliates, despite any competitors' advertising strategies (Oliver, 1999). Electronic loyalty (hereafter, e-loyalty) is an extension of brand loyalty from traditional to online products/services (Luarn and Lin, 2003). E-loyalty is determined explicitly by customers' favorable attitudes toward online businesses, resulting in repurchasing behavior on their websites or through shopping apps (Anderson and Srinivasan, 2003). Reichheld and Schefter (2000) studied the purchasing patterns on leading electronic commerce sites and found that e-loyalty and brand loyalty (in the traditional outlets) are similar. The definition of e-loyalty comes from the classical customer behavior theory and is a combination of behavior and attitude (Valvi and Fragkos, 2012).

However, Toufaily et al., (2013) also concluded that the e-loyalty phenomenon is an extension of the loyalty given to the traditional market because behavior is less stable in the electronic context than in the real context. E-loyalty research is based on loyalty research studying traditional shopping methods (Toufaily et al., 2016). Lin et al.. (2018); Sadeghi et al., (2019); Vijay et al., (2019) measured e-loyalty based on Anderson and Srinivasan (2003); Srinivasan et al., (2002), which was based on the traditional loyalty scales of Gremler (1996); Zeithaml et al., (1996). In the context of a rapidly growing digital economy, the concept of loyalty in the online environment is an important concept for companies, and many studies have focused on e-loyalty (Toufaily et al., 2013). Therefore, there should be more scholarly efforts to study customer loyalty and the expression of loyalty in online shopping (Iqbal et al., 2018; Nguyen et al., 2018; Sitorus and Yustisia, 2018). This study proposes the development of a scale to better understand the multidimensional 
psychological basis of loyalty in the online context, and its continuous development in the research landscape, i.e., the recent development of s-commerce. The e-loyalty research should come from a community's perspective, in which the customer is socially integrated, with relationships which infer and direct his or her choices on social media (Handarkho, 2020). Unlike in traditional electronic commerce (e-commerce; i.e., business website) or e-markets (i.e., Amazon), sellers and buyers can exchange and communicate with each other through the simultaneously public and private space of social networking sites; therefore, the development and validation of a scale for loyalty in the context of s-commerce is essential (Yeon et al., 2019).

This study aimed to develop and validate an e-loyalty scale based on the three dimensions of Srivastava and Rai (2018) in the context of s-commerce. The study proceeded as follows. First, this research presents an understanding of e-loyalty. Then, this study describes the definitions and dimensions of e-loyalty in s-commerce. The next section encompasses the process of developing the scales and discussions. Finally, the paper ends with our conclusions, limitations, and suggestions for further research.

\section{Literature Review}

\section{E-loyalty and scales used in previous research}

Electronic loyalty is also known as online loyalty (Valvi and Fragkos, 2012). The intention to keep engaging in transactions on an e-commerce website is also considered to be e-loyalty (Doong et al., 2008). Many authors refer to loyalty to as "a customer's favorable attitude towards an electronic business" , accompanied by an individual's repetitive behavior (Liang et al., 2008; Nguyen and Khoa, 2019b). As shown in Table 1, customers' e-loyalty is expressed through their attitude, i.e., positive perception or recommend-

Table 1. The definitions of electronic loyalty

\begin{tabular}{|c|c|}
\hline Definition & Source \\
\hline $\begin{array}{l}\text { Electronic loyalty is the bias (that is, because of preference) and behavior (that is, pur- } \\
\text { chasing) over time, by one or more decision-makers, including several alternatives and } \\
\text { derived from a psychological process (evaluation of alternatives, decisions). }\end{array}$ & Pee et al., (2018) \\
\hline $\begin{array}{l}\text { Electronic loyalty is the favorable attitude of a customer toward an online business } \\
\text { that leads to repeated purchase behavior. }\end{array}$ & Srinivasan et al., (2002) \\
\hline $\begin{array}{l}\text { Electronic loyalty is to intend to continue dealing with the same online retailer and to } \\
\text { recommend this retailer to other customers. }\end{array}$ & Gefen (2002) \\
\hline $\begin{array}{l}\text { Electronic loyalty is the degree to which consumers are willing to buy from their favor- } \\
\text { ite online retailer. }\end{array}$ & Grondin (2003) \\
\hline $\begin{array}{l}\text { Electronic loyalty is a priority attitude and behavior over the alternatives offered by } \\
\text { other online providers. }\end{array}$ & Wallace et al., (2004) \\
\hline $\begin{array}{l}\text { Electronic loyalty shows the consumers attach their psychology and support for online } \\
\text { service providers and are willing to maintain the business relationship. }\end{array}$ & Liang et al., (2008) \\
\hline Electronic loyalty is an intention to buy more from online sellers in the future & Doong et al., (2008) \\
\hline $\begin{array}{l}\text { Electronic loyalty is the intention to revisit an e-commerce site or consider purchasing } \\
\text { from an e-commerce site in the future. }\end{array}$ & $\begin{array}{l}\text { Cyr (2008); Lin et al., } \\
(2018)\end{array}$ \\
\hline $\begin{array}{l}\text { Electronic loyalty is to spend a lot of time browsing e-commerce sites and returning to } \\
\text { e-commerce sites. }\end{array}$ & Deng and Poole (2010) \\
\hline
\end{tabular}


ing the business to other customers (Khoa, 2020b; Srinivasan et al., 2002); behavior, i.e., repurchases and revisits (Deng and Poole, 2010; Grondin, 2003); and a combination of attitude and behavior, i.e., intending to revisit the website and willingness to maintain a long-term relationship with the business (Cyr, 2008; Lin et al., 2018; Wallace et al., 2004).

In the study of e-loyalty, researchers have used both a unidimensional scale (Srinivasan et al., 2002) and a multidimensional scale (Harris and Goode, 2004). The literature review revealed eight e-loyalty scales with one item and 62 scales with 2 to 16 items. Of the 62 scales, 23 were determined by the authors, and 39 were converted from scales used in previous works on traditional loyalty. Researchers have adopted these scales in many fields, including e-commerce, business, marketing, and information science. This research showed that e-loyalty is a complex field that has received a great deal of attention in many industries. The number of items in a scale group ranges from 1 to 16 . The study of Zeithaml et al., (1996) had a significant influence on the theory of e-loyalty, and many authors have adopted it to measure e-loyalty. Also, the scale used by Oliver (2014) has been used to measure customer loyalty in various studies. An e-loyalty scale with only one observed item was used in Koufaris (2002), and Shankar et al., (2003), and had the highest impact rate. Among the author-determined scales, the ones by Vatanasombut et al., (2008) have been adopted by other researchers many times (Bo et al., 2020; Mahmoud, 2019). The original e-loyalty scales of Gefen and Straub (2000); Srinivasan et al., (2002) have been frequently used and adjusted. Besides, some studies have measured e-loyalty based on psychological dimensions (Chu and Yuan, 2013) or behavior/action (Khoa, 2020a) or a combination of them (Valvi and West, 2013).
Al-dweeri et al., (2019) measured customer loyalty with Oliver (1999); however, action loyalty is no different to purchase intent loyalty and behavioral loyalty. The heterogeneity of the e-loyalty scale and the lack of research about e-loyalty in the context of s-commerce has created the opportunity for further research; therefore, this research focused on a multidimensional e-loyalty scale to achieve a deeper understanding of how the customers demonstrate their loyalty in s-commerce.

\section{E-loyalty dimensions in s-commerce}

As mentioned earlier, loyalty involves complex contrasts because of its dimensions. Loyalty is considered to be general loyalty when it only has one dimension to explain the long-term relationship between the customer and seller (Evanschitzky et al., 2012). From another perspective, loyalty can be viewed in terms of two dimensions: attitude and behavior (Vijay et al., 2019). Rather and Hollebeek (2019) stated there were three dimensions of loyalty: attitude, behavior, and a combination of attitude and behavior. Moreover, loyalty has been described as cognitive, affective, conative, and active (Al-dweeri et al., 2019; Oliver, 1997). The diversity of the traditional loyalty scales leads to diversity in e-loyalty. Valvi and West (2013) mentioned a one-dimensional scale for e-loyalty, called loyalty with a positive attitude. Kaya et al., (2019) used the behavior intention dimension of attitudinal loyalty, and Alonso-Dos-Santos et al., (2020) recommended using intentional loyalty to measure e-loyalty.

In research into the mechanism to create customer loyalty, Srivastava and Rai (2018) defined three characteristics of customer loyalty: preference, patronage, and premium. The preference is made up of repurchase intentions, switching resistance, and exclusive 
purchases; patronage includes strong preferences, the willingness to recommend, and altruism; finally, the premium can be measured by price insensitivity, exclusivity, and identification. This result can be seen as the antecedent for further loyalty research, which shows that e-loyalty should be studied as a multidimensional concept to gain a clear meaning of loyalty.

Commercial activity has changed rapidly since the birth of the internet. E-commerce has gradually replaced traditional commerce in developed countries, and that trend is spreading to developing countries (Kapurubandara and Lawson, 2006; Khoa, 2020c). Continuously changing technology is also a positive factor in the change of transaction methods in commerce, i.e., the web 1.0, which was gradually replaced by the web 2.0 (Balaji and Murthy, 2019). The explosion of social networking sites such as Facebook, Instagram, Twitter, and Zalo has created a new business environment. Trading on a new platform has introduced customers to new experiences, resulting in new kinds of responses; e-loyalty to websites is one of those new customer responses (Shafiee and Bazargan, 2018).

First, when customers are loyal to s-commerce sites, it is because they prefer them to others. A preference is established when buyers can access their social network account on mobile devices, which is now popular. Brand awareness plays a vital role in developing organizations' marketing strategies because one of the many main goals of companies is to achieve a prominent position in their customers' minds (Alnsour and Tayeh, 2019). Preference cements the brand's name and characteristics in customers' minds; the extent ranges from identification, recall, top of the mind, and brand dominance to brand knowl- edge (Aaker, 2012). Preference is critical because it lays the foundation for an intentional purchase (Kotler et al., 2019). E-loyalty on an s-commerce site makes the customer prioritize searching for products, choosing the site for their online shopping needs, and giving the website's name when asked where they shop (Srivastava and Rai, 2018).

Second, in s-commerce, patronage is related to interaction. First, interaction allows a search process to quickly locate a desired product or service, reducing the customers' dependence on having a detailed memory (Padmavathy et al., 2019). By replacing consumers' dependence on their memory with an interactive search process, an online retailer can increase the perceived value consumers expect in a transaction. Second, interaction significantly increases the amount of information presented to a customer. The customer can like, share, comment, or review a shop on numerous social networks (Apenes Solem, 2016). A recent study found a secure connection between Facebook and the brain's reward center. When the researcher received positive feedback on Facebook, that feeling lit up this area. The customer can interact with, or leave comments on the s-commerce sites, spend time giving reviews even though the s-commerce site does not offer any compensation, or track an s-commerce page (Westaby et al., 2016). The higher the intensity from using Facebook and social networks, the higher the feeling of pleasure.

Finally, the advantage of s-commerce is personalization. A social network system such as Facebook can recommend products and services to its users based on data collected from their behavior on the web or information they provide during the transaction. Identification is one of the most important parts of showing a customer's loyalty to a 
website (Srivastava and Rai, 2018). Four different perspectives are presented on privacy: a right, a commodity, a situation, and a need for control (Smith et al., 2011). Martin et al., (2017) hold that private data is an economic commodity. From the commodity perspective, privacy has a personal and social value, along with an economic value, although this does not always apply, and it may be subject to a cost-benefit analysis on both the personal and social scale. Based on the exchange theory, "secondary exchange" is a nonmonetary exchange of customers' personal information so that they can receive a higher value, such as quality service and personalized or discounted offers (Smink et al., 2019). In other words, the object of the exchange is privacy, which is like a commodity. Individuals disclose their personal information if they find that such disclosure's overall benefits are at least balanced or greater than the perceived risks of the information's disclosure (Nguyen and Khoa, 2019a). They argue that a positive outcome makes a person more likely to accept the loss of privacy that comes with disclosing any personal information, as long as the level of risk tolerance is lower than the benefits they receive (Smith et al., 2011; Xu et al., 2011).

The dimensions of e-loyalty in s-com- merce research are the preference, interaction, and personal information's disclosure (Srivastava and Rai, 2018). This conclusion was the same for all three aspects of traditional loyalty: attitude (preference), behavior (interaction), and a combination of attitude and behavior (personal information's disclosure, which is the acceptance of the risk of giving personal information to s-commerce sites). In the next section, this study presents the development of an e-loyalty scale for s-commerce.

\section{Methodology}

\section{Scale development and validation pro- cess}

A measurement scale must be rigorous in describing what is included and excluded from the structure (Churchill, 1979). This research aimed to develop and validate a scale that introduces a new measurement method for the concept, so it was appropriate to use mixed methods to ensure its reliability (De la Garza Carranza et al., 2020; DeVellis, 2017). Many mixed-method procedures are available; however, this study used two phases of a sequential exploratory strategy. First, this

Table 2 . The process of development and the validity of the e-loyalty scale

\begin{tabular}{lrl}
\hline $\begin{array}{l}\text { Scale generation and Initial } \\
\text { purification }\end{array}$ & Scale refinement & Scale validity \\
\hline $\begin{array}{l}\text { - Theoretical overview } \\
\text { - Group discussion creates an }\end{array}$ & $\begin{array}{l}\text { Exploratory factor anal- } \\
\text { initial pool of items }\end{array}$ & $\begin{array}{l}\text { Second-order CFA (sec- } \\
\text { ond-order reflective model) }\end{array}$ \\
- Coding & Testing the reliability of & - Evaluating the nomological \\
- Face validity & scale (Cronbach's alpha) & validity \\
- Interraterreliability & First-order confirmato- & - Forming a final scale \\
- Initial purification & Evaluation of reliability, \\
& the validity of the con- \\
& struct \\
\hline
\end{tabular}


strategy aimed to collect and process qualitative data, and then conduct a survey and analysis of the quantitative data as a follow-up (Creswell and Creswell, 2017). As a result, the findings were based on the combination of a qualitative and quantitative analysis. This research strategy has been used in testing the elements of an emerging theory (Morgan, 1998). Creswell (2009) pointed out that the sequential exploratory strategy is often used for scale development and validation. Therefore, in this study, the initial item groups of e-loyalty were created after reviewing the previous literature. The scale development process is described in Table 2.

\section{Scale generation}

A focus group discussion is a discussion among research participants under the guidance of researchers to provide information on a specific topic. The opinions collected through interviews and group discussions are more in-depth than those collected through standard questionnaires (Creswell and Creswell, 2017). Qualitative research using group discussion methods reveals a wide range of perspectives on a specific topic, and clarifies differences of opinion among the participants (Rabiee, 2004). Group discussions give those participants flexibility and freedom of speech, allowing them to solve problems and address obstacles in a more natural setting (Silverman, 2016). Data collected from group discussions are often more valuable than indepth discussions (Rabiee, 2004). This study conducted group discussion with seven participants who were fluent in s-commerce and marketing (online consumers, online marketing experts) to screen for duplicated items and modify some items excerpted from the previous studies. The snowball sampling method was used to select the participants, to ensure the interviews' reliability and quality (Neuman, 2013). This study selected the snowball sampling method for two reasons. First, this study needed to have auditors specializing in management, consumer behavior, and e-commerce to evaluate the e-loyalty items' content in the context of s-commerce. Second, e-commerce is growing rapidly in Vietnam; however, most consumers shop via websites rather than social media stores; therefore, finding respondents with real s-commerce experience was not easy. Therefore, this study selected suitable candidates for this phase based on recommendations from the participants. The average age of the discussion group's members ranged from 21 to 45 years old; they often buy from s-commerce sites such as Facebook and Zalo. Moreover, this research tried to interview customers with different demographics (age, education level, annual income, occupation). The duration of the discussions ranged from 90 to 120 minutes. The host recorded all the discussions.

Two people with a master's degree in marketing were invited to code the different main units based on the discussions. They worked independently during the listening and coding process. The units could be organized systematically for content analysis in the initial filtering (Kassarjian, 1977). Four experts, including two online marketing experts and two experts who each hold a Ph.D. in business administration, formed a panel to check each unit's face validity. They combed through each unit to delete those with illogical content and ambiguous wording. They examined each unit carefully based on the following criteria: "very relevant," "slightly relevant," and "very irrelevant" (DeVellis, 2017; Taherdoost, 2016). Then, the units were categorized by their relevance to different themes. 
Next, four marketing professors assessed the interrater reliability of the groups of themes qualitatively. They read out, sorted, and resorted each theme's units to identify the available content. If the themes were higher than $80 \%$ of the interrater reliability (Kassarjian, 1977), they were interpreted as measurable items.

\section{Initial purification}

The goal in developing scales was to ensure the content's validity in which: (1) All critical aspects of the conceptual definition were reflected in the scale. (2) The observed items did not overlap to the extent that they were confusing and were not part of another conceptual domain. (3) The items were expressed appropriately (MacKenzie, 2003). This study used the thematic content validity to reveal, assess, and explain customer perceptions of e-loyalty in the context of s-commerce. Specialists (four marketing professors) verified the items' clarity and uniformity, leading to the addition, modification, and deletion of some items; the remaining items were considered in the next step.

The process of scale generation and initial purification, based on the literature review, focus groups, and the unit filter by evaluating the face validity, included 19 items on the e-loyalty scale.

\section{Scale refinement (Study 1)}

The next step was to refine the e-loyalty scale with an exploratory factor analysis (EFA) and then to assess the reliability of the scale (Cronbach's alpha) with first-order confirmatory factor analysis (CFA).

\section{Scale validity (Study 2)}

The result of the scale development and scale refinement process yielded a three-di- mensional construct of e-loyalty in s-commerce. This study validated the research scales in the previous step to form the final scale in this section. This study then collected data again, analyzed the new data with a second-order CFA (second-order reflective model), and evaluated the new scale's nomological validity with the other related constructs.

\section{Sampling and data collection}

The sample came from the Vietnam E-Business Index 2020 Report; the cities with the highest index are Ho Chi Minh City, $\mathrm{Ha}$ Noi City, Hai Phong City, Da Nang City, and Binh Duong Province (IDEA., 2020). Ho Chi Minh City in southern Vietnam has the highest E-Business Index Rank 2020, 89.1, and a population of over 10 million, made up of many people who migrated from other provinces in Vietnam. Therefore, the population characteristics in Ho Chi Minh City reflect those of the population nationwide. $\mathrm{Ha}$ Noi City ranks second, (85.7), followed by Hai Phong City (60.6), Da Nang City (58.4), and Binh Duong Province (54.9).

The research focused on two social networking sites, Facebook and Zalo, which are the most popular social networks in Vietnam; $95 \%$ of the population uses Facebook, and $74 \%$ use Zalo (Datarepotal.com, 2019). Facebook is an international social networking site, whereas Zalo is a local site developed by VNG, a Vietnamese enterprise. The demographic characteristics of Facebook users vary widely, including pupils, students, housewives, and office workers from 15 to 60 years old. They spend a great deal of time on social networking sites updating their status and sharing information and interacting with friends (Khoa and Khanh, 2019). Zalo 
Gadjah Mada International Journal of Business - September-December, Vol. 22, No. 3, 2020

users are mostly office workers, lecturers, and public servants aged 25 to 45 , and they mainly use mobile apps to maintain contact with people and share information about their daily activities, including shopping (Datarepotal.com, 2019). Therefore, they are suitable for evaluating e-loyalty for s-commerce.

\section{The sample for study 1}

The purpose of this phase was to refine the measurement tool based on psychological attributes. The refinement phase consisted of a quantitative research method, using an online self-administered questionnaire that had a nonprobability sampling purpose, with $300 \mathrm{MBA}$ and Ph.D. students who majored in business administration, e-commerce, and information technology at the Industrial University of Ho Chi Minh City. A sample comprising of students was convenient because of the limited time and financial constraints, and because the authors are lecturers at this university. Besides, these respondents have training at the postgraduate level and experienceof electronic commerce and electronic marketing; they understand both the practice and the theory for electronic transactions. The items were measured on a fivepoint scale (from $1=$ strongly disagree to 5 $=$ strongly agree) to facilitate evaluation and analysis with SPSS and AMOS software. The items were arranged in a random order. The respondents were asked to rate their e-loyalty to the s-commerce sites where they shop most often. The response rate of this survey was $92 \%$; 276 respondents were qualified for further analysis. The incomplete responses were ones with missing responses or repeated the same response when evaluating different observed items.

Regarding the respondents' characteristics, the sample consisted of $50.4 \%$ females and $49.6 \%$ males. The respondents were MBA students and Ph.D. students; $50.7 \%$ of the respondents majored in business administration, 30.4\% majored in e-commerce, and $18.8 \%$ majored in information technology. Most of the respondents made purchases 3 to 5 times per month $(60.9 \%)$, and some did

Table 3. Sample Descriptive Statistics

\begin{tabular}{llrrrrr}
\hline \multirow{2}{*}{ Characteristics } & \multicolumn{3}{c}{ Sample 1 (N = 276) } & \multicolumn{3}{c}{ Sample 2 (N = 439) } \\
\cline { 2 - 7 } Gender & Male & $\mathbf{n}$ & $\mathbf{0}$ & $\mathbf{n}$ & $\mathbf{\%}$ \\
\hline \multirow{2}{*}{ Female } & 137 & 50.4 & Male & 217 & 49.4 \\
& First-year & 139 & 49.6 & Female & 50.6 & 22.6 \\
& Second year & 32 & 11.6 & Below 20 & 64 & 14.6 \\
& Third year & 79 & 28.6 & $20-24$ & 124 & 28.2 \\
& Fourth year & 94 & 34.1 & $25-29$ & 89 & 20.3 \\
& Other & 67 & 24.3 & $30-34$ & 63 & 14.4 \\
& Business administration & 140 & 50.7 & Student & 142 & 32.3 \\
Major/Occupation & Information technology & 52 & 18.8 & Lecturer & 71 & 16.2 \\
& E-commerce & 84 & 30.4 & Office worker & 226 & 51.5 \\
Social commerce & 1-2 time(s) & 53 & 19.2 & $1-2$ time(s) & 80 & 18.2 \\
3-5 times & 168 & 60.9 & $3-5$ times & 271 & 61.7 \\
& More than 5 times & 55 & 19.9 & More than 5 times & 88 & 20.0 \\
\hline
\end{tabular}


so more than five times per month $(19.9 \%)$. This research sample is presented in Table 3.

\section{The sample in study 2}

This study performed a further data collection to validate the scale. These s-commerce customers were 18 years old and over (Vietnam eCommerce and Digital Economy Agency, 2019). The respondents were students, white-collar workers, and lecturers, who often buy online and were aware of good s-commerce sites. Of the 450 questionnaires distributed, 443 were returned, of which 439 had usable responses and were processed with SPSS and AMOS software after those with missing information were deleted. The sampling method used purposive sampling. The sample pool consisted of $49.4 \%$ males and $50.6 \%$ females. The age groups were divided as follows: under 20 years old $(22.6 \%)$, 20 to 24 years old $(14.6 \%), 25$ to 29 years old $(28.2 \%), 30$ to 34 years old $(20.3 \%)$, and over 34 years old $(14.4 \%)$; regarding their occupations, $32.3 \%$ are students, $16.2 \%$ are lecturers, and the remaining $51.5 \%$ are office workers. Those who made purchases 3 to 5 times/month made up $61.7 \%$ of the final usable responses (Table 3).

\section{Results}

\section{Scale generation}

Some statements showed the customer's engagement with an online store on a social network-for example, "rarely consider switching," "the first choice for purchasing," and "like to use." Some of the respondent's statements described a positive attitude about the sales page, such as "my favorite retail site," "is better than other companies," "prefer the social commerce site," and "like the features." Acts that show loyalty were also mentioned, such as "continue to choose," "continue to support," "prefer to use the social commerce site," "recommend the company," and "spend time every day going to the social commerce site." The focus group discussion yielded several items adapted from the context of social networking technology, Web 2.0, and Industry 4.0, such as "like," "share," "comment," and "review" (Apenes Solem, 2016). Moreover, the self-disclosure of personal information in loyalty programs was mentioned, i.e., "disclose an interest," and "share personal ideas," such as the respondent's loyalty to the business (Campbell, 2019). Thereafter, two people with a master's degree in marketing coded the responses into 53 different items for the next analysis. The evaluation panel generated 32 themes from the 53 items based on their surface validity. Consequently, 32 themes were assessed for their interrater reliability. Kassarjian (1977) pointed out that an agreement ratio of $80 \%$ or higher in coding decisions is acceptable. Our interrater reliability was $91 \%$, easily exceeding the threshold of $80 \%$. A pool of 32 items indicating e-loyalty was formed from these 32 themes, which are presented in Table 4.

Table 4. The initial pool of scale items for e-loyalty in social commerce

\footnotetext{
Statements about customer loyalty in social commerce

1. Rarely consider switching to another s-commerce site.

2. Use the s-commerce site whenever a purchase is needed.

3. This s-commerce site is my first choice when I need to buy something.
} 


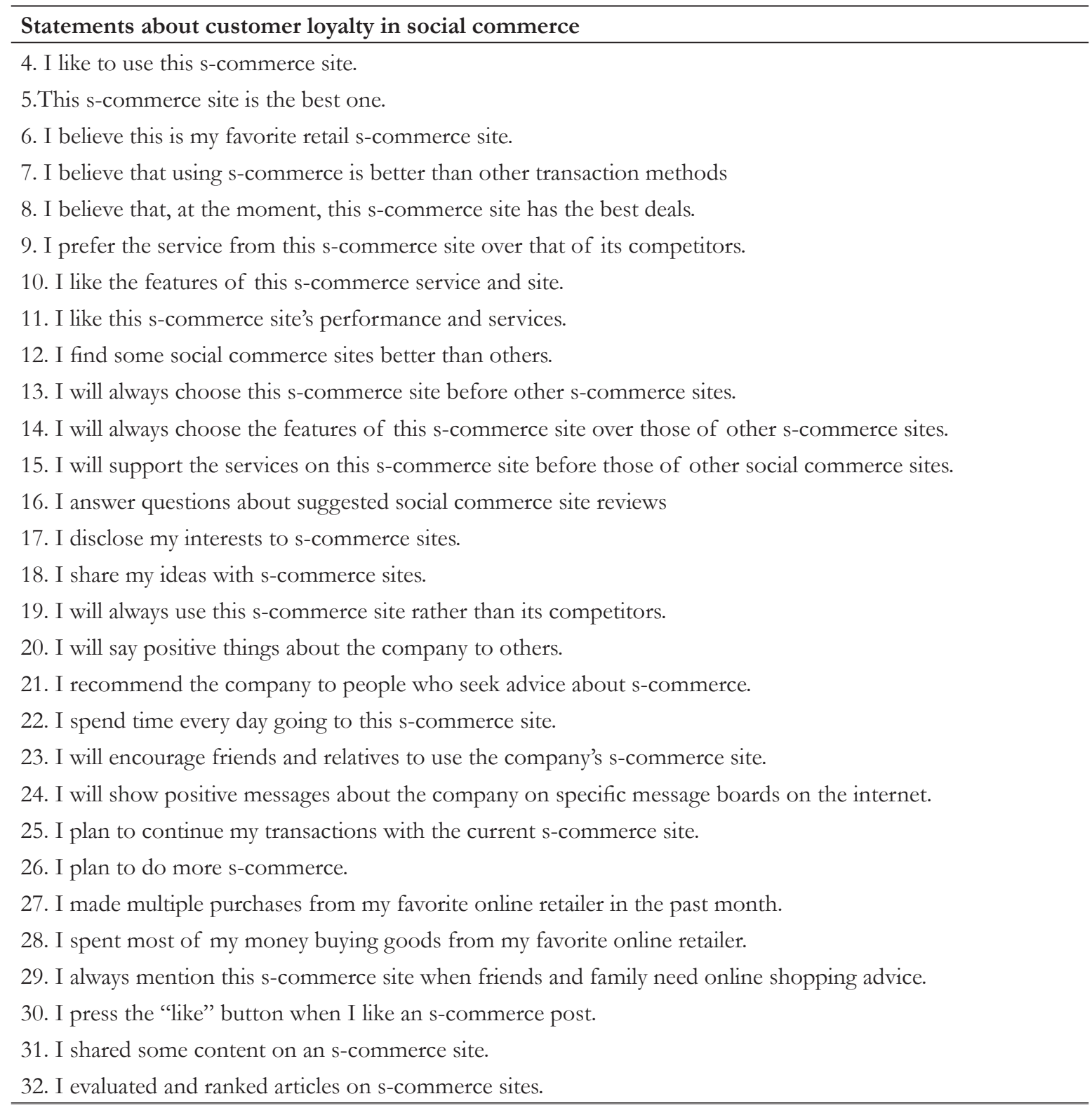

The initial purification used content validity to define the research items with the same meaning or express satisfaction, rather than loyalty. There is a big difference between satisfaction and loyalty. Customer satisfaction is the expression of a customer's attitude toward products, services, and brands; therefore, enterprises know whether customers view the company's products or brands positively. Customer loyalty goes further and shows the extent to which customers think that a business or product exceeds their expectations, such as saying it is awesome or enjoyable (Wiresa, 2017). The initial purification deleted 13 items and retained 19 items, as seen in Table 5 . Nineteen items were added to the questionnaire used in the survey. In the survey questionnaire, these items were used to assess the respondents' agreement with a five-point Likert scale from 1 (strongly disagree) to 5 (strongly agree). 
Table 5. Scale items retained after item filtering

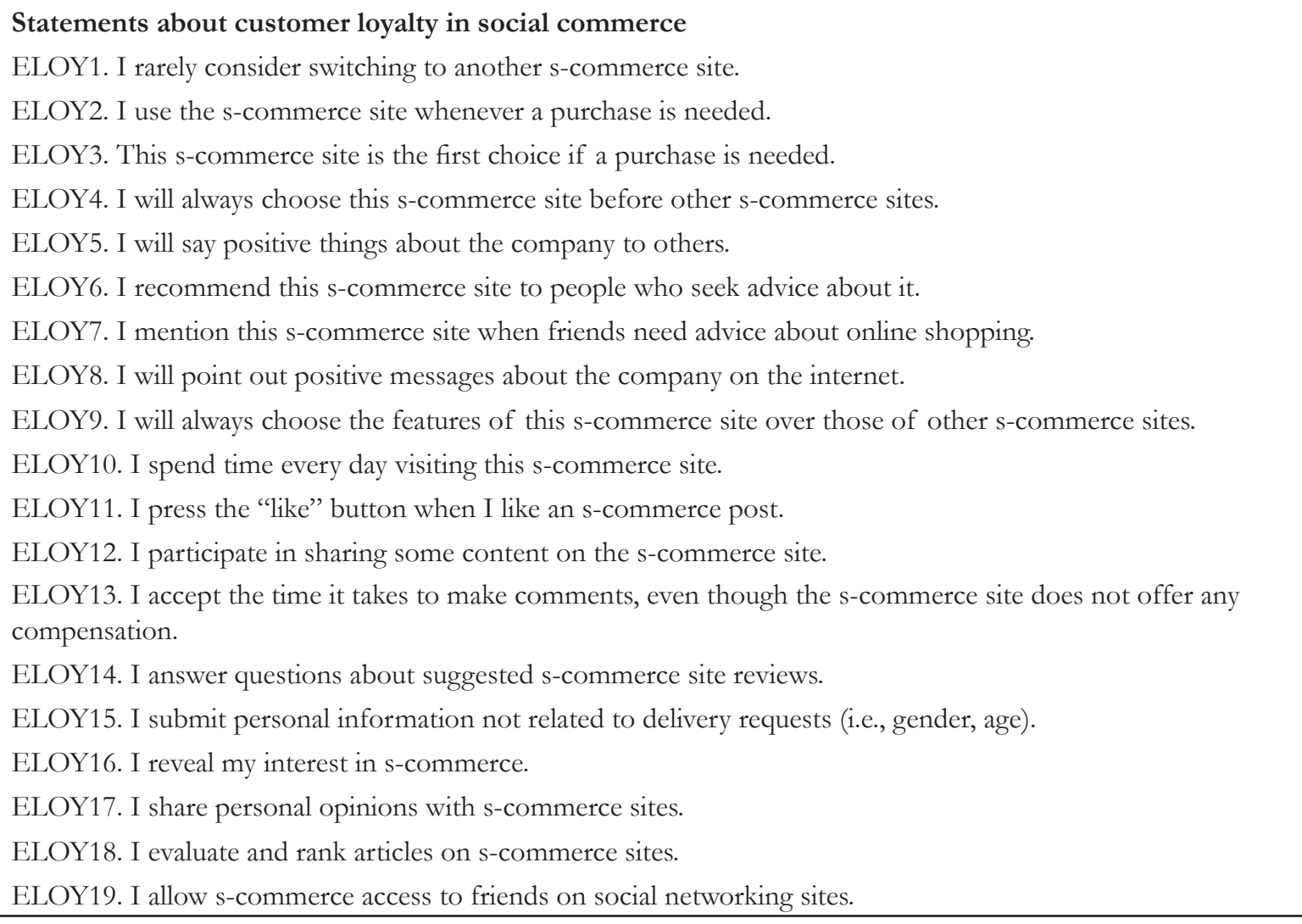

\section{Study 1. Scale refinement}

\section{EFA and the reliability assessment of the scale}

EFA is an analytical technique that reduces many observed items into fewer factors but retains most of the informational content and statistical significance of the first group of items (Hair et al., 2010). Each item observed is calculated with a ratio called a factor loading, which defines these factors. This research used principal axis factoring and the Promax rotation method because they reflect the data's structure more accurately than the principal components extraction method with Varimax rotation (Meyers et al., 2013).

The factor analysis model was appropriate when the following criteria were met: (1)
Although a minimum loading factor from 0.3 to 0.4 is acceptable, a ratio greater than 0.5 is generally considered necessary for practical meaning (Hair et al., 2010). (2) The factor analysis is deemed suitable at $0.5 \leq \mathrm{Kai}-$ ser - Meyer - Olkin value $(\mathrm{KMO}) \leq 1$. (3) Cumulative variance is the percentage of the total variance extracted by factors. A factor analysis with a higher than $50 \%$ variance is accepted if the eigenvalue is greater than 1.0 (Tabachnick and Fidell, 2007).

This research examined 19 observable items measuring e-loyalty with the EFA process using SPSS software. The results in Table 6, after EFA was performed five times, showed that the observed items were extracted into three groups, with a total variance extracted of $59.682 \%>50 \%$; therefore, the scale was accepted. The KMO coefficient 
Gadjah Mada International Journal of Business - September-December, Vol. 22, No. 3, 2020

Table 6. The result of EFA

\begin{tabular}{llllllll}
\hline Time & KMO & Sig & Eigenvalue & $\begin{array}{l}\text { Variance } \\
\text { explained }\end{array}$ & Factors & Eliminated items & Reason \\
\hline 1 & 0.815 & 0.00 & 1.030 & 42.524 & 7 & $\begin{array}{l}\text { ELOY4,ELOY9, } \\
\text { ELOY10, ELOY14 }\end{array}$ & Factor loadings $<0.5$ \\
2 & 0.824 & 0.00 & 1.018 & 50.062 & 5 & ELOY1, ELOY8 & \\
3 & 0.828 & 0.00 & 1.103 & 54.235 & 4 & ELOY5 & Factor with one item \\
4 & 0.835 & 0.00 & 1.041 & 58.784 & 4 & ELOY6 & - \\
\hline 5 & 0.846 & 0.00 & 1.586 & 59.682 & 3 & - & \\
\hline
\end{tabular}

was 0.846 , within $0.5 \leq \mathrm{KMO} \leq 1$; therefore, the factor analysis was appropriate. The Bartlett test with sig. was $0.00<0.05$ and had a high level of significance.

The EFA result showed eight observed items (ELOY1, ELOY3, ELOY4, ELOY6, ELOY8, ELOY9, ELOY10, ELOY14) were excluded from the study; the other items were qualified as reliable for further research.
The summary of the scale for proper research is as follows:

- Factor 1 consisted of four observed items: ELOY15, ELOY16, ELOY17, and ELOY19.

- Factor 2 consisted of four observed items: ELOY11, ELOY12, ELOY13, and ELOY18

- Factor 3 consisted of three observed items: ELOY2, ELOY3, and ELOY7

Table 7. The result of the final EFA

\begin{tabular}{|c|c|c|c|c|c|}
\hline \multicolumn{6}{|c|}{ Factor } \\
\hline & 1 & 2 & 3 & Cronbach's alpha & Smallest correlation coefficient \\
\hline ELOY15 & 0.866 & & & \multirow{4}{*}{0.880} & \multirow{4}{*}{0.715} \\
\hline ELOY16 & 0.806 & & & & \\
\hline ELOY19 & 0.795 & & & & \\
\hline ELOY17 & 0.741 & & & & \\
\hline ELOY18 & & 0.797 & & \multirow{4}{*}{0.825} & \multirow{4}{*}{0.637} \\
\hline ELOY12 & & 0.727 & & & \\
\hline ELOY11 & & 0.711 & & & \\
\hline ELOY13 & & 0.706 & & & \\
\hline ELOY7 & & & 0.824 & \multirow{3}{*}{0.804} & \multirow{3}{*}{0.619} \\
\hline ELOY2 & & & 0.748 & & \\
\hline ELOY3 & & & 0.709 & & \\
\hline
\end{tabular}

All the factor loadings for each item in the group were higher than 0.5 . The test of the reliability of newly discovered scales showed that all the factors were valid, and the Cronbach's alpha coefficients were greater than 0.7 ; the smallest correlation coefficient of the variables in each scale group was greater than 0.3; the evaluation's result is presented in Table 7.
The EFA results and the reliability test of the scale showed that e-loyalty, in the context of s-commerce, was measured through three factors with 11 observed items. Based on the theory and the results of the discussion with the five experts, this study formed an e-loyalty scale, as shown in Table 8.

Factor 1 had four items, encompassing "personal information's disclosure," which 
Table 8. Scale refinement of e-loyalty

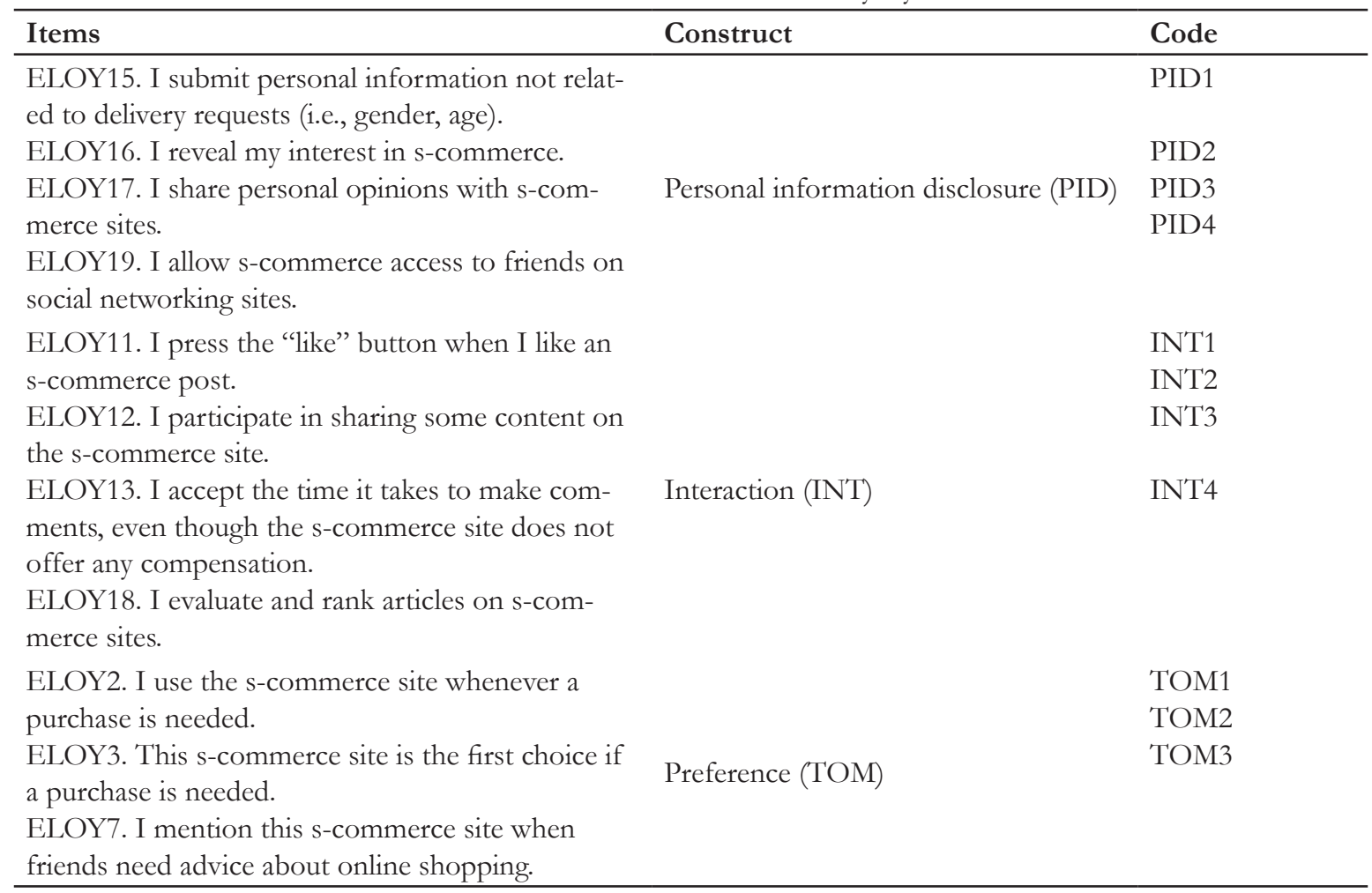

showed that customers provided personal information, even private information, to s-commerce sites. This result was consistent with studies into business loyalty programs. The customers must agree to provide the businesses with information to participate and obtain benefits (Campbell, 2019; Zanchett and Paladini, 2019); moreover, customers allowed familiar s-commerce sites to access their contacts' social networks. This scale was also in line with the theory of loyalty that combines attitude, behavior, and a premium (Srivastava and Rai, 2018).

Factor 2 had four items, encompassing "interaction." This scale showed the interaction behavior between customers and s-commerce sites in the social networking era and web 2.0. When accessing s-commerce sites, customer actions included clicking the like button, sharing posts, making comments, rating, and reviewing (Apenes Solem, 2016;
Holland and Baker, 2001). The interaction showed the customer's loyalty to the s-commerce site and formed part of their patronage of the site (Srivastava and Rai, 2018).

Factor 3 had three items, encompassing "preference," as in Srivastava and Rai (2018). This factor is a concept related to brand loyalty (Jacoby and Chestnut, 1978), signifying that customers always think of products, find products, or first choose products on an s-commerce site with which they are familiar or have previous experience. Customers can also recommend an s-commerce site with which they are familiar to their friends, relatives, and colleagues (Latif and Uslu, 2019).

\section{Confirmatory factor analysis (CFA)}

The maximum likelihood estimation was used to test the first-order three-factor model with relationships between the items and 
Gadjah Mada International Journal of Business - September-December, Vol. 22, No. 3, 2020

scales. The best criteria to assess the measurement model included the chi-square/dfindex $(\mathrm{CMIN} / \mathrm{df}) \leq 2$, in some cases, CMIN/df $\leq$
The minimum CR of three dimensions was 0.81 , greater than the threshold of 0.7 (Table 9).

Table 9. The result of CFA of the first-order e-loyalty model

\begin{tabular}{|c|c|c|c|c|}
\hline Construct & Items & Standardized & CR & AVE \\
\hline \multirow{4}{*}{ Personal information disclosure } & PID1 & 0.844 & \multirow{4}{*}{0.88} & \multirow{4}{*}{0.65} \\
\hline & PID2 & 0.828 & & \\
\hline & PID3 & 0.780 & & \\
\hline & PID4 & 0.769 & & \\
\hline \multirow{3}{*}{ Preference } & TOM1 & 0.743 & \multirow{3}{*}{0.81} & \multirow{3}{*}{0.58} \\
\hline & TOM2 & 0.713 & & \\
\hline & TOM3 & 0.828 & & \\
\hline \multirow{4}{*}{ Interaction } & INT1 & 0.722 & \multirow{4}{*}{0.82} & \multirow{4}{*}{0.54} \\
\hline & INT2 & 0.757 & & \\
\hline & INT3 & 0.723 & & \\
\hline & INT4 & 0.747 & & \\
\hline \multirow{2}{*}{$\begin{array}{l}\mathrm{CMIN}=41.786 ; \mathrm{df}=41 ; \\
\mathrm{CMIN} / \mathrm{df}=1.019\end{array}$} & GFI & CFI & TLI & RMSEA \\
\hline & 0.973 & 0.999 & 0.999 & 0.008 \\
\hline
\end{tabular}

3 (McIver and Carmines, 1981); goodness-offit index $(\mathrm{GFI})>0.9$; comparative fit index $(\mathrm{CFI})>0.9$; Tucker and Lewis index $(\mathrm{TLI})>$ 0.9; and root mean square error of approximation (RMSEA) index $\leq 0.08$ or RMSEA $\leq 0.05$ (Steiger, 1990). The findings in Table 9 significantly support an e-loyalty model with three dimensions when all the values are within the threshold (Hair et al., 2010; McIver and Carmines, 1981; Steiger, 1990).

\section{The construct reliability}

Composite reliability (CR) is a better choice than Cronbach's alpha for checking construct reliability (Anderson and Gerbing, 1988). A scale's reliability is guaranteed when the CR is greater than 0.7 (Hair et al., 2010).

\section{The construct validity}

Construct validity was assessed through convergent validity, which confirmed that a group of items represented the construct (Chau, 1997), and discriminant validity, which is the difference between two constructs (Hulland, 1999). Three criteria were used to assess the convergent validity: (1) The value of CR was 0.7 or above. (2) The value of the average variance extracted (AVE) was greater than 0.5. (3) The value of all the item loadings in the construct was greater than 0.7 (Fornell and Larcker, 2018; Nunnally, 1978). The CR satisfied the requirement, and the AVE of the three scales was greater than 0.5 . Furthermore, all the factor loadings in each construct were higher than 0.7 (Table 9). Therefore, all

Table 10. The result of discriminant validity

\begin{tabular}{lllllll}
\hline & & & R & SE. & CR & P-value \\
\hline PID & $<-->$ & TOM & 0.342 & 0.057 & 11.59 & 0.000 \\
PID & $<->$ & INT & 0.422 & 0.055 & 10.55 & 0.000 \\
TOM & $<-->$ & INT & 0.401 & 0.055 & 10.82 & 0.000 \\
\hline
\end{tabular}


three scale measurements achieved convergent validity. In Table 10, the three constructs have discriminant validity because their $\mathrm{R}$ values (correlation value) are lower than 1.0 (Anderson and Gerbing, 1988).

\section{Study 2. The scale validity}

\section{The second-order $C F A$}

The second-order CFA model showed a fit on the dataset collected. All the measurement indicators conformed to testing standards $(\mathrm{GFI}=0.963>0.9 ;$ TLI $=0.960>$ $0.9 ; \mathrm{CFI}=0.970>0.9 ; \mathrm{RMSEA}=0.056<$ 0.08 ; chi-square $/ \mathrm{df}=2.358<3$ ). The scale reliability was ensured when the CR of all the

\section{The nomological validity}

The research tested the relationship between the constructs of e-loyalty and the theoretical constructs in previous studies to assess the e-loyalty scale's nomological validity. This study assessed the causal relationship between e-loyalty and its antecedents, such as the perceived hedonic value (Chiu et al., 2018; Eid, 2011) and online trust (Cyr, 2008; Gefen, 2002).

The research scales were adapted from previous studies, i.e., the scale for the perceived hedonic value was measured by four items (Lee and Wu, 2017), and online trust was measured by five items (Liu and Tang, 2018). The reliability of these scales was checked with CFA. This study examined the

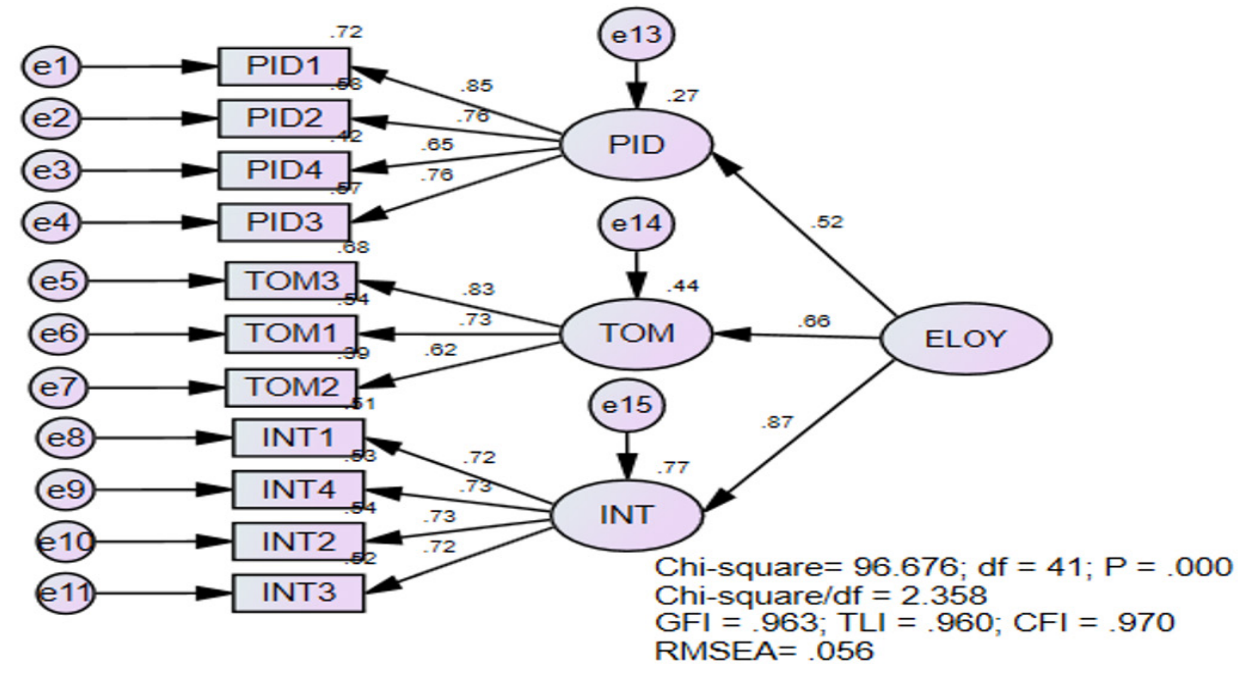

Figure 1. Second-order CFA results

dimensions was more than 0.7. Moreover, all the AVEs were greater than 0.5, and the standardized regression weights of the first- and second-order scales were significantly greater than the threshold of 0.5 . In addition, the correlations between the dimensions were less than 1.0, with $p<0.001$. Thus, Figure 1 shows a reasonable model fit for the second-order construct of e-loyalty. correlation values between online trust and the perceived hedonic value with the three dimensions of e-loyalty, to assess the nomological validity of the e-loyalty scale in s-commerce.

Table 11 shows that the standardized regression weights of observed items were more than 0.5 ; the $\mathrm{CR}$ of the online trust and the perceived hedonic value were greater 
Gadjah Mada International Journal of Business - September-December, Vol. 22, No. 3, 2020

Table 11. The reliability and validity of antecedentof e-loyalty

\begin{tabular}{lllll}
\hline Construct & Items & Standardized & CR & AVE \\
\hline & HV1 & 0.855 & & \\
Perceived hedonic value (HV) & HV2 & 0.814 & 0.913 & 0.724 \\
& HV3 & 0.923 & & \\
HV4 & 0.807 & & \\
OT1 & 0.857 & 0.616 \\
Online trust (OT) & OT2 & 0.721 & \\
& OT3 & 0.792 & & \\
\hline
\end{tabular}

than 0.7, and the AVE exceeded 0.5.

The results of Table 12 show that online trust was highly correlated with interaction (0.518) as well as the correlation with the concept of preference (0.380) and personal information's disclosure (0.316). Similarly, the perceived hedonic value had a strong correlation with the dimensions of e-loyalty in s-commerce, in particular, personal information's disclosure (0.375), interaction (0.583), ence (TOM), interaction (INT), and the disclosure of personal information to the seller (PID).

The scale was consistent with general customer psychology, the Vietnamese market, and the context of s-commerce. The e-loyalty scale has been studied for a long time but was mainly based on the traditional loyalty scale. The research indicated that e-loyalty demonstrates the cognitive aspect of loyal custom-

Table 12. The correlation matrix of the online trust, perceived hedonic value,

\begin{tabular}{llllll}
\multicolumn{6}{c}{ and e-loyalty } \\
\hline OT & OT & HV & PID & INT & TOM \\
HV & 1 & & & & \\
PID & 0.515 & 1 & & & \\
INT & 0.316 & 0.375 & 1 & 1 & \\
TOM & 0.520 & 0.583 & 0.460 & 1 & 1 \\
\hline
\end{tabular}

and preference (0.370) (Hair et al., 2010). Online trust and the perceived hedonic value were significantly correlated with the three dimensions $(p<0.001)$; therefore, the proposed scale had nomological validity (Shimp and Sharma, 1987).

\section{Discussion}

Qualitative and quantitative research validated the three dimensions of e-loyalty in the context of s-commerce, including prefer- ers by prioritizing certain s-commerce sites. When shopping online, their priority was to search for products on s-commerce sites, or the first site they think of, when asked to define loyalty when shopping on s-commerce sites (Dick and Basu, 1994; Terci, 2000). Also, e-loyalty for web 2.0 was described through the customers' interaction with s-commerce. A higher frequency of using Facebook increased their feeling of excitement.

Similarly, interaction expressed that the customer would leave comments on s-com- 
merce sites and spend time giving reviews, even though the s-commerce sites do not offer any compensation, and try to track s-commerce pages (Godes et al., 2005; Westaby et al., 2016). Lastly, e-loyalty was manifested by providing personal information to s-commerce sites. Loyalty programs require customers to exchange a great deal of personal information to obtain better service. Chellappa and Sin (2005) suggested that personalization refers to modifying products and the purchasing experience to suit the individual consumer. New advances in the collection of information and processing technology have enabled online suppliers to offer various personalized products or services in s-commerce, which increases their engagement with customers and the importance of enticing customers to provide valuable information.

Among the three dimensions of e-loyalty in s-commerce so far discovered, personal information's disclosure receives the most attention because it introduces many risks for customers, i.e., privacy risk, financial risk, psychological risk, and time risk (Featherman and Hajli, 2016). Disruptive technology is an innovation that significantly alters how consumers or businesses operate and cannot be controlled in the global information age. The disclosure of personal information also creates risks for customers and may leave them vulnerable. Thus, the disclosure of personal information is an important issue for customers, and they tend to withhold their information for the sake of their privacy and security (Gracia and Juliadi, 2019). In other words, consumers tend to have an adverse reaction to any data collection efforts and are not willing to share personal data (Palmatier and Martin, 2019). Many customers are satisfied with personalized shopping from businesses through relevant product recommen- dations. Besides, over $69 \%$ of customers are willing to provide personal information to receive the most suitable product or service suggestions (Zanchett and Paladini, 2019). Personalized customer experience is also one strategy to help businesses develop their customers' loyalty (Kartajaya et al., 2019). Products and services that meet customers' needs, requirements, and use ensure their trust in their choices and motivate them to repeat the experience in the future. In location-based services, customers disclose their GPS position to get a discount from a shop (Xu et al., 2011). Loyalty is described as the customer's willingness to provide personal information on an s-commerce site (Albashrawi and Motiwalla, 2019; Campbell, 2019).

These components are consistent with the theory of marketing as well as the behavioral theory. First, loyalty refers to the belief that a brand or seller is a better match for a customer than others; so this research focused on customers' emotions. Second, interaction reflects a favorable or preferable attitude based on customers' satisfaction. Third, conscious loyalty constitutes behavioral intentions characterized by a deeper level of commitment via personal information disclosures. The final stage is behavioral loyalty, in which customers convert intentions into actions (Sadeghi et al., 2019). At this stage, customers experience inertia, along with the desire to overcome obstacles to purchasing. Although behavioral loyalty is ideal, it is difficult to observe and measure. Therefore, most researchers tend to study one stage of the behavior, normally one of the first three stages. The e-loyalty scale's development and validation here include attitude, behavior, and a combination of attitude and behavior. The same is true for preference; this result explored the dimensions of e-loyalty, includ- 
Gadjah Mada International Journal of Business - September-December, Vol. 22, No. 3, 2020

ing the premium and patronage (Srivastava and Rai, 2018).

\section{Conclusion}

This research makes both theoretical and practical contributions. Amid the explosion of current research, it is crucial to narrow the scope of essential concepts, such as e-loyalty. In particular, developing an e-loyalty scale in the context of s-commerce enriches the theory. First, this paper developed and validated an e-loyalty scale for s-commerce as a three-dimensional concept with three components: preference, interaction, and personal information's disclosure. This result has not been mentioned in previous studies of e-loyalty. Moreover, the research is relevant to developing countries, especially regarding information security issues, when free online services, such as search sites (Google), social networks (Facebook and Zalo), are widely used. Although information is seen as a commodity in a for-profit transaction in developed countries (Smith et al., 2011), it is a novelty in developing countries; hence, this research's result affirms that information is a commodity and lays the foundation for further research related to online businesses in developing countries.

This study's practical contribution is showing online businesses, especially in the context of s-commerce, that building customer loyalty is paramount. Increasing services or features to make it easier for customers to access and shop for goods is important for so- cial networking sites. With the 2.0 technology platform, businesses should facilitate their customers interactions by setting up buttons and allowing customers to leave feedback and reviews, or post product reviews. Lastly, loyalty programs should be considered after customers disclose their personal information. Personalization in advertising, product recommendations, and customer care is essential for a business.

\section{Limitation}

Despite our best efforts, our study has some limitations. Although the data were collected from the four largest cities and a province in Vietnam, which are highly developed in terms of technology, their representativeness did not meet the researchers' expectations. To confirm the credibility and value of the e-loyalty scale, it would be helpful to conduct a wide-ranging study of other cities or countries with different levels of economic development. An in-depth analysis of e-loyalty in the context of s-commerce is necessary to obtaina clear perception of the scale. In addition to s-commerce's development, mobile commerce has become an emerging phenomenon in Southeast Asian and developing countries. Further research is needed to compare and develop an e-loyalty scale related to the context of $\mathrm{m}$-commerce. Finally, the nonprobability sampling method also limits the research's reliability, which needs to be improved using appropriate and accurate sampling frames with the probability sampling method. 


\section{References}

Aaker, DA 2012. Building strong brands. London: Simon and Schuster.

Al-dweeri, R.M., Ruiz Moreno, A., Montes, F.J.L., Obeidat, Z.M. and Al-dwairi, K.M. 2019. The effect of e-service quality on Jordanian student's e-loyalty: an empirical study in online retailing. Industrial Management and Data Systems 119(4): 902-923.

Albashrawi, M. and Motiwalla, L. 2019. Privacy and personalization in continued usage intention of mobile banking: An integrative perspective. Information Systems Frontiers 21(5): 10311043.

Alnsour, M. and Tayeh, Z.A. 2019. Impact of social media use on brand awareness: an applied study on Jordanian banks that uses Facebook. International Journal of Electronic Banking 1(4): 341-357.

Alonso-Dos-Santos, M., Soto-Fuentes, Y. and Valderrama-Palma, V.A. 2020. Determinants of Mobile Banking Users' Loyalty. Journal of Promotion Management 26(5): 615-633. doi: 10.1080/10496491.2020.1729312

Anderson, J.C. and Gerbing, D.W. 1988. Structural equation modeling in practice: A review and recommended two-step approach. Psychological Bulletin 103(3): 411-423. doi: 10.1037//0033-2909.103.3.411

Anderson, R.E. and Srinivasan, S.S. 2003. E-satisfaction and e-loyalty: A contingency framework. Psychology and marketing 20(2): 123-138.

Apenes Solem, B.A. 2016. Influences of customer participation and customer brand engagement on brand loyalty. Journal of Consumer Marketing 33(5): 332-342. doi: 10.1108/jcm04-2015-1390

Balaji, P. and Murthy, S.S. 2019. Web 2.0: An Evaluation of Social Media Networking Sites. International Journal of Innovative Technology and Exploring Engineering 8(10): 752-759.

Bo, W., Jin, Y. and Kwon, O. 2020. Effects of Artificial Intelligence Functionalities on Online Store'S Image and Continuance Intention: A Resource-Based View Perspective. The Journal of Society for e-Business Studies 25(2): 65-98.

Campbell, D. 2019. A Relational Build-up Model of Consumer Intention to Self-disclose Personal Information in E-commerce B2C Relationships. AIS Transactions on Human-Computer Interaction 11(1): 33-53. doi: 10.17705/1thci.00112

Chau, P.Y. 1997. Reexamining a model for evaluating information center success using a structural equation modeling approach. Decision Sciences 28(2): 309-334.

Chellappa, R.K. and Sin, R.G. 2005. Personalization versus Privacy: An Empirical Examination of the Online Consumer's Dilemma. Information Technology and Management 6(2-3): 181202. doi: 10.1007/s10799-005-5879-y

Chiu, Y.-L., Chen, L.-J., Du, J. and Hsu, Y.-T. 2018. Studying the relationship between the perceived value of online group-buying websites and customer loyalty: the moderating role of referral rewards. Journal of Business and industrial marketing 33(5): 665-679.

Chu, K.-M. and Yuan, J. 2013. The effects of perceived interactivity on e-trust and e-consumer behaviors: the application of fuzzy linguistic scale. Journal of Electronic Commerce Research 14(1): 124-136.

Churchill, G.A. 1979. A paradigm for developing better measures of marketing constructs. Jour- 
Gadjah Mada International Journal of Business - September-December, Vol. 22, No. 3, 2020

nal of Marketing Research 16(1): 64-73.

Creswell, J.W. 2009. Mapping the field of mixed methods research. Los Angeles: Sage.

Creswell, J.W. and Creswell, J.D. 2017. Research design: Qualitative, quantitative, and mixed methods approaches. London: Sage.

Cyr, D. 2008. Modeling web site design across cultures: relationships to trust, satisfaction, and e-loyalty. Journal of Management Information Systems 24(4): 47-72.

Datarepotal.com. 2019. Digital 2019: Vietnam [online]. Available at: https://datareportal.com/ reports/digital-2019-vietnam.

De la Garza Carranza, M.T., López Lemus, J.A., Guzmán Soria, E. and Atlatenco Ibara, Q. 2020. Validation of a measuring scale of the expectations of millennials at work, the Mexican case. Gadjah Mada International Journal of Business 22(2): 78-198. doi: 10.22146/gamaijb.51212

Deng, L. and Poole, M.S. 2010. Affect in web interfaces: a study of the impacts of web page visual complexity and order. Mis Quarterly 34(4): 711-730.

DeVellis, R.F. 2017. Scale development: Theory and applications. 4th ed. Los Angeles: Sage.

Dick, A.S. and Basu, K. 1994. Customer loyalty: toward an integrated conceptual framework. Journal of the academy of marketing science 22(2): 99-113.

Doong, H.S., Wang, H.C. and Shih, H.C. 2008. Exploring loyalty intention in the electronic marketplace. Electronic Markets 18(2): 142-149.

Eid, M.I. 2011. Determinants of e-commerce customer satisfaction, trust, and loyalty in Saudi Arabia. Journal of Electronic Commerce Research 12(1): 78-93.

Evanschitzky, H., Ramaseshan, B., Woisetschläger, D.M., Richelsen, V., Blut, M. and Backhaus, C. 2012. Consequences of customer loyalty to the loyalty program and to the company. Journal of the academy of marketing science 40(5): 625-638.

Featherman, M.S. and Hajli, N. 2016. Self-service technologies and e-services risks in social commerce era. Journal of Business Ethics 139(2): 251-269.

Fornell, C. and Larcker, D.F. 2018. Evaluating Structural Equation Models with Unobservable Variables and Measurement Error. Journal of Marketing Research 18(1): 39-50. doi: $10.1177 / 002224378101800104$

Gefen, D. 2002. Customer loyalty in e-commerce. Journal of the Association for Information Systems 3: 27-51.

Gefen, D. and Straub, D. 2000. The Relative Importance of Perceived Ease of Use in IS Adoption: A Study of E-Commerce Adoption. Journal of the Association for Information Systems 1(1): 1-30. doi: 10.17705/1jais.00008

Godes, D., Mayzlin, D., Chen, Y., Das, S., Dellarocas, C., Pfeiffer, B., Libai, B., Sen, S., Shi, M. and Verlegh, P. 2005. The firm's management of social interactions. Marketing letters 16(3-4): 415-428.

Gracia, E. and Juliadi, R. 2019. The Threat of Personal Information Trading in the Online Network and Information Technology. International Journal of Multicultural and Multireligious Understanding 6(9): 49-55.

Gremler, DD. 1996. The effect of satisfaction, switching costs, and interpersonal bonds on service loyalty. Marketing Department. Tucson, Arizona, Arizona State University.

Grondin, B. 2003. A framework of e-loyalty levers. Canada, Concordia University. 
Hair, J.F., Anderson, R.E., Babin, B.J. and Black, W.C. 2010. Multivariate data analysis: A global perspective. Upper Saddle River, NJ: Pearson.

Handarkho, Y.D. 2020. The factors influencing customer loyalty in social commerce platform: variety-seeking and social impact perspective. International Journal of Web Information Systems 16(4): 369-386. doi: 10.1108/ijwis-04-2020-0021

Harris, L.C. and Goode, M.M.H. 2004. The four levels of loyalty and the pivotal role of trust: a study of online service dynamics. Journal of Retailing 80(2): 139-158. doi: 10.1016/j. jretai.2004.04.002

Holland, J. and Baker, SM 2001. Customer participation in creating site brand loyalty. Journal of interactive marketing 15(4): 34-45.

Hulland, J. 1999. Use of partial least squares (PLS) in strategic management research: a review of four recent studies. Strategic management journal 20(2): 195-204.

IDEA. 2020. Vietnam E-Business Index 2020 Report. Hanoi, Vietnam e-Commerce and Digital Economy Agency.

Iqbal, M.S., Ul Hassan, M., Habibah, U. and TiuWright, L. 2018. Impact of self-service technology (SST) service quality on customer loyalty and behavioral intention: The mediating role of customer satisfaction. Cogent Business and Management 5(1): 1-23. doi: 10.1080/23311975.2018.1423770

Jacoby, J. and Chestnut, R.W. 1978. Brand loyalty: Measurement and management. New York: John Wiley and Sons.

Jacoby, J. and Kaplan, L.B. 1972. The components of perceived risk. Proceedings of the third annual conference of the association for consumer research, Chicago, Association for Consumer Research.

Kapurubandara, M. and Lawson, R. 2006. Barriers to Adopting ICT and e-commerce with SMEs in developing countries: an Exploratory study in Sri Lanka. University of Western Sydney, Australia: 2005-2016.

Kartajaya, H., Kotler, P. and Hooi, D.H. 2019. Marketing 4.0: Moving From Traditional To Digital. Hoboken, NJ: John Wiley and Sons.

Kassarjian, H.H. 1977. Content analysis in consumer research. Journal of Consumer Research 4(1): 8-18.

Kaya, B., Behravesh, E., Abubakar, A.M., Kaya, O.S. and Orús, C. 2019. The moderating role of website familiarity in the relationships between e-service quality, e-satisfaction and e-loyalty. Journal of Internet Commerce 18(4): 369-394.

Khoa, B.T. 2020a. The Antecedents of Relationship Marketing and Customer Loyalty: A Case of the Designed Fashion Product. Journal of Asian Finance, Economics and Business 7(2): 195204. doi: doi.org/10.13106/jafeb.2020.vol7.no2.195

Khoa, B.T. 2020b. The Impact of the Personal Data Disclosure's trade-off on the Trust and Attitude Loyalty in Mobile Banking Services. Journal of Promotion Management ahead-ofprint(ahead-of-print). doi: 10.1080/10496491.2020.1838028

Khoa, B.T. 2020c. The role of Mobile Skillfulness and User Innovation toward Electronic Wallet Acceptance in the Digital Transformation Era. 2020 International Conference on Information Technology Systems and Innovation (ICITSI), Bandung - Padang, Indonesia, IEEE. doi: 10.1109/ICITSI50517.2020.9264967

Khoa, B.T. and Khanh, T. 2019. A study of factors affecting Online Trust of The Vietnamese 
Gadjah Mada International Journal of Business - September-December, Vol. 22, No. 3, 2020

Customers: Case of Social Commerce. Vietnam Trade and Industry Review 5 (2019): 198-204.

Kotler, P., Keller, K.L., Goodman, M., Brady, M. and Hansen, T. 2019. Marketing management. 4th ed. Harlow, UK: Pearson Education.

Koufaris, M. 2002. Applying the technology acceptance model and flow theory to online consumer behavior. Information systems research 13(2): 205-223.

Latif, F.Ö.B. and Uslu, A. 2019. Building e-loyalty for e-retailers: role of justice perception and consumer forgiveness. Middle East Journal 6(3): 298-317.

Lee, C.-H. and Wu, J.J. 2017. Consumer online flow experience: The relationship between utilitarian and hedonic value, satisfaction and unplanned purchase. Industrial Management and Data Systems 117(10): 2452-2467. doi: 10.1108/IMDS-11-2016-0500

Liang, C.-J., Chen, H.-J. and Wang, W.-H. 2008. Does online relationship marketing enhance customer retention and cross-buying? Service Industries Journal 28(6): 769-787.

Liang, T.-P. and Turban, E. 2011. Introduction to the special issue on social commerce: a research framework for social commerce. International Journal of Electronic Commerce 16(2): 5-14.

Lin, C.-P., Chiu, C.-K., Liu, C.-M., Chen, K.-J. and Hsiao, C.-Y. 2018. Modeling e-loyalty: a moderated-mediation model. Service Industries Journal 38(15-16): 1160-1178.

Liu, Y. and Tang, X. 2018. The effects of online trust-building mechanisms on trust and repurchase intentions: An empirical study on eBay. Information Technology and People 31(3): 666687. doi: doi.org/10.1108/ITP-10-2016-0242

Luarn, P. and Lin, H.-H. 2003. A customer loyalty model for e-service context. Journal of Electronic Commerce Research 4(4): 156-67.

MacKenzie, S.B. 2003. The dangers of poor construct conceptualization. Journal of the academy of marketing science 31(3): 323-326.

Mahmoud, M.A. 2019. Gender, E-Banking, and Customer Retention. Journal of Global Marketing 32(4): 269-287.

Martin, K.D., Borah, A. and Palmatier, R.W. 2017. Data privacy: Effects on customer and firm performance. Journal of Marketing 81(1): 36-58.

McIver, J. and Carmines, E.G. 1981. Unidimensional scaling. London: Sage.

Meyers, L.S., Gamst, G.C., and Guarino, A. 2013. Performing data analysis using IBM SPSS. Hoboken, NJ: John Wiley and Sons.

Morgan, D.L. 1998. Practical strategies for combining qualitative and quantitative methods: Applications to health research. Qualitative health research 8(3): 362-376.

Neuman, W.L. 2013. Social research methods: Qualitative and quantitative approaches. 7th ed. Harlow, United Kingdom: Pearson education.

Nguyen, H., Nguyen, H., Nguyen, N. and Phan, A. 2018. Determinants of Customer Satisfaction and Loyalty in Vietnamese Life-Insurance Setting. Sustainability 10(4): 1151-1167.

Nguyen, H.M., and Khoa, B.T. 2019a. The Relationship between the Perceived Mental Benefits, Online Trust, and Personal Information Disclosure in Online Shopping. Journal of Asian Finance, Economics and Business 6(4): 261-270. doi: 10.13106/jafeb.2019.vol6.no4.261

Nguyen, M.H., and Khoa, B.T. 2019b. Customer Electronic Loyalty towards Online Business: The role of Online Trust, Perceived Mental Benefits and Hedonic Value. Journal of Distribution Science 17(12): 81-93. doi: 10.15722/jds.17.12.201912.81

Nunnally, J.C. 1978. An overview of psychological measurement. In B. W. Benjamin ed. Clinical diagnosis of mental disorders. Boston, MA, Springer. pp. 97-146. 
Oliver, R.L. 1997. Loyalty and Profit: Long-term Effects of Satisfaction. In R. L. Oliver ed. Satisfaction: A behavioural perspective on the consumer. New York, McGraw-Hill. pp. 386-407.

Oliver, R.L. 1999. Whence consumer loyalty? Journal of Marketing 64(4): 33-44. doi: 10.1177/00222429990634s105

Oliver, R.L. 2014. Satisfaction: A Behavioral Perspective on the Consumer. London: Routledge.

Padmavathy, C., Swapana, M. and Paul, J. 2019. Online second-hand shopping motivation-Conceptualization, scale development, and validation. Journal of Retailing and Consumer Services 51: 19-32.

Palmatier, R.W. and Martin, K.D. 2019. Understanding and Valuing Customer Data. In R. W. Palmatier and K. D. Martin eds. The Intelligent Marketer's Guide to Data Privacy. Cham, Palgrave Macmillan. pp. 133-151.

Rabiee, F. 2004. Focus-group interview and data analysis. Proceedings of the nutrition society 63(04): 655-660. doi: 10.1079/pns2004399

Reichheld, F.F., and Schefter, P. 2000. E-loyalty: your secret weapon on the web. Harvard Business Review 78(4): 105-113.

Sadeghi, A., Ghujali, T. and Bastam, H. 2019. The Effect of Organizational Reputation on E-loyalty: The Roles of E-trust and E-satisfaction. ASEAN Marketing Journal 10(1): 1-16.

Shafiee, M.M. and Bazargan, N.A. 2018. Behavioral customer loyalty in online shopping: the role of E-service quality and E-recovery. Journal of Theoretical and Applied Electronic Commerce Research 13(1): 26-38.

Shankar, V., Smith, A.K. and Rangaswamy, A. 2003. Customer satisfaction and loyalty in online and offline environments. International journal of research in marketing 20(2): 153-175.

Shimp, T.A. and Sharma, S. 1987. Consumer ethnocentrism: construction and validation of the CETSCALE. Journal of Marketing Research 24(3): 280-289.

Silverman, D. 2016. Qualitative research. London: Sage.

Sitorus, T. and Yustisia, M. 2018. The influence of service quality and customer trust toward customer loyalty: the role of customer satisfaction. International Journal for Quality Research 12(3): 639-654.

Smink, A.R., Frowijn, S., van Reijmersdal, E.A., van Noort, G. and Neijens, P.C. 2019. Try online before you buy: How does shopping with augmented reality affect brand responses and personal data disclosure. Electronic Commerce Research and Applications 35: 100854. doi: 10.1016/j.elerap.2019.100854

Smith, H.J., Dinev, T. and Xu, H. 2011. Information privacy research: an interdisciplinary review. MIS quarterly 35(4): 989-1016.

Srinivasan, S.S., Anderson, R. and Ponnavolu, K. 2002. Customer loyalty in e-commerce: an exploration of its antecedents and consequences. Journal of Retailing 78(1): 41-50.

Srivastava, M. and Rai, A.K. 2018. Mechanics of engendering customer loyalty: A conceptual framework. IIMB management review 30(3): 207-218. doi: 10.1016/j.iimb.2018.05.002

Steiger, J.H. 1990. Structural model evaluation and modification: An interval estimation approach. Multivariate behavioral research 25(2): 173-180.

Tabachnick, B. and Fidell, L. 2007. Multivariate analysis of variance and covariance. Using multivariate statistics 3: 402-407.

Taherdoost, H. 2016. Validity and Reliability of the Research Instrument; How to Test the Validation of a Questionnaire/Survey in a Research. International Journal of Academic Research in 
Gadjah Mada International Journal of Business - September-December, Vol. 22, No. 3, 2020

Management 5(3): 28-36. doi: 10.2139/ssrn.3205040

Terci, S. 2000. Reasons for brand awareness: an exploratory study. Curitiba, UFPR.

Toufaily, E., Fallu, J.-M. and Ricard, L. 2016. OCL: Online Customer Loyalty in the Service Industries: Scale Development and Validation. Journal of Relationship Marketing 15(4): 269-298. doi: 10.1080/15332667.2016.1209067

Toufaily, E., Ricard, L. and Perrien, J. 2013. Customer loyalty to a commercial website: Descriptive meta-analysis of the empirical literature and proposal of an integrative model. Journal of Business Research 66(9): 1436-1447.

Turban, E., Outland, J., King, D., Lee, J.K., Liang, T.-P. and Turban, DC 2017. Electronic Commerce 2018: A Managerial and Social Networks Perspective. Cham, Switzerland: Springer.

Valvi, A.C. and Fragkos, K.C. 2012. Critical review of the e-loyalty literature: a purchase-centred framework. Electronic Commerce Research 12(3): 331-378.

Valvi, A.C. and West, DC 2013. E-loyalty is not all about trust, price also matters: extending expectation-confirmation theory in bookselling websites. Journal of Electronic Commerce Research 14(1): 99-123.

Vatanasombut, B., Igbaria, M., Stylianou, AC and Rodgers, W. 2008. Information systems continuance intention of web-based applications customers: The case of online banking. Information and management 45(7): 419-428.

Vietnam eCommerce and Digital Economy Agency. 2019. Vietnam E-Commerce White Paper 2019 [online]. Hanoi. Available at: http://www.idea.gov.vn/file/ef6314a6-709e-4d42-a2fab60457a66179 [Accessed May 25 2020].

Vijay, T.S., Prashar, S. and Sahay, V. 2019. The Influence of Online Shopping Values and Web Atmospheric Cues on E-Loyalty: Mediating Role of E-Satisfaction. Journal of theoretical and applied electronic commerce research 14(1): 1-15.

Wallace, D.W., Giese, J.L. and Johnson, J.L. 2004. Customer retailer loyalty in the context of multiple channel strategies. Journal of Retailing 80(4): 249-263.

Westaby, J.D., Woods, N. and Pfaff, D.L. 2016. Extending dynamic network theory to group and social interaction analysis: Uncovering key behavioral elements, cycles, and emergent states. Organizational Psychology Review 6(1): 34-62.

Wiresa, A. 2017. Customer Satisfaction $\neq$ Customer Loyalty [online]. Available at: https://www.andrewiringa.com/customer-satisfaction- $\% \mathrm{E} 2 \% 89 \% \mathrm{~A} 0$-customer-loyalty $/$.

Xu, H., Luo, X., Carroll, J.M. and Rosson, M.B. 2011. The personalization privacy paradox: An exploratory study of decision making process for location-aware marketing. Decision support systems 51(1): 42-52. doi: 10.1016/j.dss.2010.11.017

Yeon, J., Park, I. and Lee, D. 2019. What creates trust and who gets loyalty in social commerce? Journal of Retailing and Consumer Services 50: 138-144.

Zanchett, R. and Paladini, E.P. 2019. Consumer loyalty programs: impact of different modalities. Dyna 86(208): 206-213. doi: 10.15446/dyna.v86n208.71080

Zeithaml, V.A., Berry, L.L. and Parasuraman, A. 1996. The behavioral consequences of service quality. Journal of Marketing 60(2): 31-46. 